\title{
研究グループ紹介
}

\section{立命館大学理工学部電子光情報工学科 高倉研究室}

\section{高倉 秀行 (光機能デバイス研究室)}

\section{1. 高倉研究室概要}

太陽光発電技術は, 風力発電技術とともに 21 世紀を支え るクリーンエネルギーとして大きな期待が寄せられている が, 依然として発電コストが高いことと, 発電が不安定で 計画的な発電が行えないことが大規模に普及する妨げとな っており，この課題を解決する技術の開発が求められてい る。高倉研究室では, これまでの高効率太陽電池開発の経 験を生かして, 直流送配電技術を中心としたスマートグリ ッド技術の開発を中心に, 新型太陽電池開発の開発から, 太陽光発電システムの屋外実証試験まで総合的に研究して いる。

\section{2. 各研究テーマ}

（1）直流エネルギー変換を用いたスマートグリッド技 術の開発

太陽光発電で得られた電気エネルギーは, 現在主として これを交流に変換し, 交流配電網に接続して利用する, い わゆる系統連係が中心となっている。低炭素社会の実現と, 脱原子力の流れから, 太陽光発電を電力会社が所有する発 電設備の $20 \%$ るいは 30\%程度にまで増加させるといった 計画が進められているが, 計画発電ができない発電設備が 系統に数多く接続されると, 交流配電網が不安定となり, 多くの問題が発生することが懸念されている。当研究室で は, この問題の解決のため, 直流エネルギー変換ならびに 直流送電技術を用いた，新しいコンセプトのスマートグリ ッド構築のための実証試験を行っている。実験設備は, 太 陽光発電装置, 蓄電装置, $\mathrm{DC} / \mathrm{DC}$ 変換器, 燃料電池などか ら構成され, 特に, 蓄電サイズの最適化, ならび最適運用 モードの確立を目指した研究を行っている。

（2）直流エネルギー変換技術を用いた太陽光発電シス テムの安定動作に関する研究

太陽光発電システムは, 20 年以上の寿命が必要とされる が，10 年以上連続して動作させたシステムでは, 太陽電池 モジュールの劣化や, 周辺の街並みの変化による影の影響 などが, 発電システムの出力を大きく低下させる要因とな っている。これは, 太陽光発電システムでは, 交流に変換 し系統連係するため, 太陽電池モジュールを直列接続し, $300 \mathrm{~V}$ 程度の直流を発生させているためで, 約 600 個の太陽 電池が直列接続されている。この太陽電池の一部が劣化し たり, 影が入ったりして発電電流が低下寸ると, その影響
が全体に及ぶためである。この課題を解決するための方法 として, 当研究室では, DC/DC 変換技術を用いた新たな発 電システムの構築に向けた研究を行っている。具体的には, 太陽電池モジュール毎に DC/DC 変換器を取り付け, それを 直並列するシステムとする計画で, 現在その高効率化と運 転モードの確立に向けた研究を行っている。

（3）高効率太陽電池開発のための基礎特性測定技術の 開発

太陽電池の構造は, 基本的には大面積の pn 接合であり, 他の半導体素子と比較して, かなり単純な構成であるが, エネルギー変換効率が高いことが求められることから, 表 面パシベーションや表面テクスチャー技術など, 特有の高 効率化技術が導入されている。これらの半導体処理技術を 開発する上で，それらの試みがどのように性能を決めてい るかを, 基礎特性評価を通して明確にすることが, 高効率 化研究のために必要である。当研究室では, これまでの太 陽電池素子開発で培ってきた経験を活用して, 総合的な診 断システムを構築してきている。研究では, 暗電流電圧特 性, 接合容量特性, 波長感度特性といった太陽電池素子の 基礎特性の計測技術を学生に学ばせると共に, 新たに必要 となるセル評価技術を確立するため, 自動計測装置の開発 を目指した研究を行っている。

（4）新型太陽電池の研究（高効率・低コストの実現）

$\mathrm{Cu}(\mathrm{In}, \mathrm{Ga}) \mathrm{Se}_{2}$ (CIGS と略す) 系太陽電池は薄膜太陽電池 の中でも最も変換効率が高く, 長期信頼性も実証されてい ることから, 次世代型太陽電池として注目されている。当 研究室では, CIGS をはじめとして, $\mathrm{CuInS}_{2}$ や $\mathrm{Cu}_{2} \mathrm{ZnSnS}_{4}$ などの新材料にも取り組んでいる。さらに, 太陽電池用中 空シリコン球の製造技術開発も行っている。

（5）太陽光発電システムの動作解析

太陽電池は, 通常 $50^{\circ} \mathrm{C}$ 前後の素子温度ならびに刻一刻変 わる太陽光入射の条件下で動作することから, 同じ効率の モジュールであっても, 年間発電量は一定でないため, こ れを評価する手法が求められている。当研究室では, 大学 内 2 か所に設置されている, 太陽光発電フィールドテスト 施設の長期間の屋外動作データに基づき, 太陽光発電シス テムの発電量予測に取り組むと共に, その国際基準作りに 参加している。

(2011 年 11 月 24 日受付) 